\title{
Spontan Vajinal Doğum Yapan Hastalarda Maternal Serum Beyin Kaynaklı Nörotrofik Faktör ve Malondialdehit Düzeylerindeki Değişimlerin Araştırılması
}

Investigating The Changes In Maternal Serum Brain-Derived Neurotrophic Factor Levels In Patients Undergoing Spontaneous Vaginal Delivery

\section{Ayşe Nur AKSOY *, İlay GÖZÜKARA *, Suna Kabil KUCUR * Gonca BATMAZ **, Esra LALOĞLU ***, Elif BULUT ****}

(*) Nenehatun Kadın Doğum Hastanesi, Kadın Hast. ve Doğum Bölümü, Erzurum, Türkiye

$\left({ }^{* *}\right)$ Bezmialem Vakıf Üniversitesi Tıp Fakültesi, Kadın Hastalıkları ve Doğum Anabilim Dalı, İstanbul, Türkiye

${ }^{(* * *}$ Atatürk Üniversitesi Tıp Fakültesi, Biyokimya Bölümü, Erzurum, Türkiye

$\left.{ }^{(* * *}\right)$ Ondokuz Mayıs Üniversitesi İktisadi ve İdari Bilimler Fakültesi, İşletme Bölümü, Samsun, Türkiye

\section{$\ddot{O Z Z E T}$}

Amaç: Spontan vajinal doğum eylemindeki kadınlarda maternal serum beyin kaynaklı nörotrofik faktör (BDNF) ve malondialdehit (MDA) seviyelerinde oluşan değişiklikleri ortaya koymak.

Metod: Bu prospektif çalışma, spontan vaginal doğum eylemindeki term gebeligi olan 62 hastada yapıldı. Dogumun latent fazında ( $\left.T_{1}\right)$, göbek kordonu klemplenmeden hemen önce $\left(T_{2}\right)$ ve doğumdan 24 saat sonra $\left(T_{3}\right)$ maternal kan örnekleri; doğumda göbek kordonu klemplendikten hemen sonra umblikal arterden kord kanı örneği alındl. Alınan kan örneklerindeki MDA ve BDNF seviyeleri ölçüldü ve uygun istatistik testler kullanilarak sonuçlar karşılaştırıldı. Kord kanı BDNF ile kord kanı $M D A$ seviyeleri ve maternal serum BDNF ile maternal serum MDA seviyeleri arasındaki ilişki araştırıld.

Bulgular: $T_{3}$ zamanindaki maternal serum BDNF seviyeleri $(\mathrm{pg} / \mathrm{ml})(3729,92 \pm 621,68) T_{1}(956,75 \pm 291,47)$ ve $T_{2}(985,50 \pm 291,91)$ 'den yüksek bulundu $(P<0,0001$, her ikisi için). Kord kanı BDNF seviyeleri $(834,91 \pm 235,73)$ ise $T_{1}, T_{2}$ ve $T_{3}$ zamanlarinda alınan maternal serum $B D N F$ seviyelerinden daha düşüktü $(P=0,01 ; P=0,002$, $P<0,0001$; geriye dönük olarak). $T_{3}$ zamanındaki maternal serum MDA değerleri ( $\mu \mathrm{mol} / \mathrm{ml})(6,42 \pm 1,70)$, $T_{1}(8,43 \pm 2,67)$ ve $T_{2}(8,80 \pm 3,11)$ zamanlarında değerlerden daha düşük bulundu $(P<0,0001$; her ikisi için). Kord kanı MDA seviyeleri $(9,98 \pm 1,70)$ ise $T_{1}, T_{2}$ ve $T_{3}$ zamanlarinda alinan maternal serum MDA seviyelerine göre yüksekti ( $P=0,001 ; T$, için ve $P<0,0001$; $T_{1}$ ve $T_{3}$ için). Maternal serum $M D A$ ile BDNF seviyeleri arasında ve kord kanı MDA ile BDNF düzeyleri arasinda negatif korelasyon vardl $(r=-0,374$ $P<0,0001 ; r=-0,310 ; P=0,014 ;$ geriye dönük olarak).

Karar: Spontan vajinal doğum yapan kadınlarda maternal BDNF ve MDA düzeylerinde değişiklikler meydana gelir. Bu değişiklikler, doğum eylemi sirasında artan maternal oksidatif stres ile ilişkili olabilir.

Anahtar kelimeler: Spontan vajinal doğum, maternal serum, kord kanı, beyin kaynaklı nörotrofik faktör, malondialdehit.

\footnotetext{
İletişim Bilgileri:

Yazışmadan Sorumlu Yazar: Op. Dr. Ayşe Nur AKSOY

Yazışma Adresi: Nenehatun Kadın Doğum Hast. Kadın

Hast. ve Doğum Bölümü, Erzurum, Türkiye

E-mail: draysenuraksoy@hotmail.com

Tel: +905058193513
}

Makalenin Geliş Tarihi: 27.05.2014

Makalenin Kabul Tarihi: 17.11.2014

\section{ABSTRACT}

Objective: To reveal the changes in maternal serum brain-derived neurotrophic factor (BDNF) and malondialdehyde (MDA) levels in women undergoing spontaneous vaginal delivery.

Material and Method: This prospective study was done in sixty-two patients with term pregnancy undergoing spontaneous vaginal delivery. Maternal blood samples in the latent phase of labor $\left(T_{1}\right)$, immediately before clamping the umbilical cord $\left(T_{2}\right)$ and 24 hours after birth $\left(T_{3}\right)$; and umbilical artery cord blood sample immediately after umbilical cord clamping at delivery were obtained. $M D A$ and BDNF levels in collected blood samples were measured and results were compared using appropriate statistical tests. The relationship between cord blood levels of BDNF with cord blood MDA and maternal serum levels of BDNF with maternal serum MDA was investigated.

Results: Maternal serum BDNF levels ( $\mathrm{pg} / \mathrm{ml}$ ) were significantly higher in the blood sample collected at the $T_{3}$ time point (3729.92 \pm 621.68$)$ compared to blood samples collected at $T_{1}(956.75 \pm 291.47)$ and $T_{2}(985.50$ $\pm 291.91)$ time points $(P<0.0001$, for both $)$. Cord blood $B D N F$ levels $(834.91 \pm 235.73)$ were significantly lower compared to maternal blood samples collected at $T_{1}, T_{2}$ and $T_{3}$ time points $(P=0.01, P=0.002, P<0.0001$; retrospectively). Maternal serum MDA levels $(\mu \mathrm{mol} / \mathrm{ml})$ at $T_{3}$ time point (6.42 \pm 1.70$)$ were found to be lower compared with those of collected blood samples at $T_{1}(8.43 \pm 2.67)$ and $T_{2}(8.80 \pm 3.11)$ time points $(P<0.0001$, for both $)$. Also, cord blood MDA levels $(9.98 \pm 1.70)$ were higher compared to maternal serum MDA levels collected at $T$, $T_{2}$ and $T_{3}$ time points $\left(P=0.001\right.$, for $T_{2}$ and $P<0.0001$, for $T_{1}$ and $T_{3}$ time points). A negative association was found between both maternal and cord blood BDNF levels with maternal and cord blood MDA levels, respectively ( $r=$ $-0.374, P<0.0001 ; r=-0.310, P=0.014$; respectively).

Conclusion: Changes in maternal BDNF and MDA levels occur in women undergoing spontaneous vaginal delivery. These changes may be associated with increased maternal oxidative stress during labor.

Key Words: Spontaneous vaginal delivery, maternal serum, cord blood, brain derived neurotrophic factor, malondialdehyde. 


\section{GİRIŞ}

Nörotrofinler, nöronların fonksiyonlarını sürdürmesinde önemli role sahip olan hücre içi faktörlerdir. Beyin kaynaklı nörotrofik faktör (BDNF), nörotrofinlerin bir üyesi olup erişkin santral sinir sisteminde kisa ve uzun dönem nöronal yapının korunmasında oldukça önemlidir (1). BDNF, gelişme döneminde nöral kök hücrelerinin nöronlara farklılaşmasında rol alırken, erişkin beyninde travma veya iskemi gibi durumlarda nöron ölümlerini önleyerek hücre canlılığının devamına önemli katkı sağlar (2). Ayrıca BDNF, prenatal ve postnatal dönemlerde beyin gelişiminde önemli etkiye sahiptir (3). Perinatal dönemde kan beyin bariyeri immatür olduğu için dolaşımdaki BDNF'nin fetüsün santral sinir sistemindeki BDNF düzeyini yansıtabileceği ve dolaşımdaki BDNF seviyeleri ile kortikal BDNF seviyelerinin korele olduğu rapor edilmiştir (4). Prenatal stresin nöronal aktiviteyi etkilediği ve bu etkilenme sonucunda davranış ve yeme bozukluklarının ortaya çıktığ1 yönünde çalışmalar vardır $(5,6)$. Siçanlarda yapılan bir çalıșmada, prenatal dönemde maruz kalınan stresin beyin korteksinde BDNF miktarını ve sinaptik yoğunluğu azalttığı rapor edilmiştir (7). Malondialdehit (MDA) bir lipid peroksidasyon ürünü olup oksidatif stres durumunda doku MDA seviyeleri artış gösterir (8). Santral sinir sisteminde strese yol açan cerrahi stres, doğum ve hipotansiyon gibi durumlar BDNF salınımında değişikliklere sebep olur (9). Bu çalışmanın amacı; spontan vajinal dogum eylemindeki kadınlarda serum BDNF ve MDA seviyelerinde oluşan değișiklikleri ortaya koymaktır. İkincil amaç ise maternal kan BDNF seviyelerini kord kanı BDNF seviyeleri ile karşılaştırmaktır.

\section{MATERYAL VE METOD}

Bu prospektif gözlemsel çalışma; Atatürk Üniversitesi, T1p Fakültesi Etik Kurul onayı ile Helsinki kriterlerine uygun olarak ortalama 6 ay süresince gerçekleştirildi. Çalıșma öncesi her iki ebeveyn çalışma hakkında bilgilendirildi ve çalışmaya katılmayı kabul ettiklerine dair yazılı onamları alındı. Nenehatun Kadın Doğum Hastanesi Kadın Hastalıkları ve Doğum Kliniği'ne doğum için başvuran term (37 hafta ve sonrası) gebeliği olan, 20-35 yaș arası ve vücud kitle indeksi 30'un altında olan 75 hasta çalışmaya alındı. Sigara içenler, alkol kullananlar, komplike gebeliği (preeklampsi, oligohidramnioz ve plasenta previa varlığı gibi) olanlar, hipertansiyon veya diabet gibi kronik hastalığ olanlar, çoğul gebeliği olanlar ve yardımcı üreme teknikleri ile gebe kalmış olan hastalar ve yenidoğanın 1. Dakika Apgar skoru 7 ve altında olan hastalar çalıșma dıșı bırakıldı. Tüm hastalarda düzenli kontraksiyonlar mevcuttu. Doğumun aktif fazının başladığı ve servikal dilatasyonun 3-4 $\mathrm{cm}$ olduğu $T_{1}$ süresinin sonunda tüm hastalara amniotomi ile doğum indüksiyonu uyguland1. Oksitosin infüzyonu gibi başka bir indüksiyon yöntemi kullanılmadı. Opioid veya epidural analjezi gibi ağrı kesici yöntemler dogum eylemi süresince hastalara uygulanmadi. Sürekli fetal monitorizasyon ve maternal kan basıncı ölçümü tüm hastalarda yapıldı. Tüm hastaların tam kan tetkikleri normaldi ve CRP değerleri negatifti.

Maternal kan örnekleri; doğumun latent fazında (doğum eyleminin başlangıcından serviksin 3-4 cm açılışına kadar geçen zaman) $\left(T_{1}\right)$, göbek kordonu klemplenmeden hemen önce $\left(\mathrm{T}_{2}\right)$ ve doğumdan 24 saat sonra $\left(\mathrm{T}_{3}\right)$ alındi. Ayrıca doğumda göbek kordonu klemplendikten hemen sonra umblikal arterden kord kanı örneği alındı. Alınan tüm kan örnekleri 3000 g'de santrifüj edildi ve ayrilan serumlar MDA ve BDNF ölçümleri yapılana kadar $-80^{\circ} \mathrm{C}$ 'de bekletildi. Serum BDNF seviyeleri ELISA yöntemi ile üretici firmanın talimatlarına göre ölçüldü (Quantikine ${ }^{R}$, Human BDNF Immunoassay, R\&D Systems, Minneapolis, USA) ve $\mathrm{pg} / \mathrm{ml}$ biriminde sunuldu. Serum MDA seviyeleri Ohkawa ve ark. (10) tarafindan tanımlanmış olan yönteme göre ölçüldü ve $\mu \mathrm{mol} / \mathrm{ml}$ biriminde sunuldu. Hastaların sosyodemografik özellikleri (yaş, parite, gebelik haftası, vücud kitle indeksi), doğum süreleri, fetüsün doğum ağırlığ 1 , fetüsün 1. ve 5. dakika Apgar skorları, kord kanı $\mathrm{pH}$ değeri, maternal serum ve kord kanındaki BDNF ile MDA düzeyleri kaydedildi. Verilerin normal dağılıma uyup uymadığ1 Kolmogorov-Smirnov testi ile değerlendirildi. Grup içi farklılıkların tespiti için Friedman testi kullanıldı. Kord kanı BDNF ile MDA seviyeleri ve maternal serum BDNF ile MDA seviyeleri ve sosyodemografik karakterler arasındaki ilişki Spearman korelasyon testi ile araştırıldi. İstatisiksel analizler SPSS software 12.0 (SPSS Inc., Chicago, IL, USA) kullanılarak gerçekleştirildi. Veriler ortalama \pm standard sapma olarak sunuldu ve $\mathrm{P}<0,05$ olan değerler istatistiksel olarak anlamlı kabul edildi.

\section{BULGULAR}

Çalışmaya dahil olma kriterlerine uygun olan 75 hasta alındı. Bu hastalardan üç tanesi ilk kan alımından sonra çalışmadan ayrılmak istediği için, iki hasta kan örnekleri yetersiz olduğu için, dört hasta doğum eyleminin aktif fazında fetal distress nedeni ile acil sezryen ameliyat1- 
na alındığ 1 için ve dördü ise bebeğin 1. dakika Apgar skorları 7'nin altında olması nedeniyle; toplam 13 hasta çalışma dışı birakıldı. Sonuçta 62 hastanın kan örnekleri analiz edildi. Kan örnekleri analiz edilen yenidoğanların hepsinin 5 . dakika Apgar skoru ve kord kanı pH değerleri 7'nin üzerindeydi. Yalnızca sekiz yenidoğana oksijen verilerek gözlem amacıyla Yoğun Bakım Ünitesi'nde takip edildi. Hastaların klinik ve demografik özellikleri Tablo 1'de verildi. Maternal serum ve kord kanı BDNF (pg/ml) ile MDA ( $\mu \mathrm{mol} / \mathrm{ml})$ seviyeleri Tablo ,'de sunuldu. Grup içi farklılığ 1 test etmek için yapılan Friedman testi sonucunda; maternal serum BDNF seviyeleri açısından $\mathrm{T}_{1}(956,75 \pm 291,47)$ ve $\mathrm{T}_{2}(985,50 \pm 291,91)$ zamanlarındaki sonuçlar arasinda fark tespit edilmedi $(\mathrm{P}>0,05)$. Ancak $\mathrm{T}_{3}$ zamanındaki maternal serum $\mathrm{BDNF}$ düzeyi $(3729,92 \pm 621,68) \mathrm{T}_{1}$ ve $\mathrm{T}_{2}$ 'den farklı bulundu $(\mathrm{P}<0,0001$; her ikisi için). Kord kanı BDNF seviyeleri $(834,91 \pm 235,73)$ ise $T_{1}, T_{2}$ ve $T_{3}$ zamanlarındaki maternal serum $\mathrm{BDNF}$ seviyelerinden düşüktü $(\mathrm{P}=0,01 ; \mathrm{P}=0,002 ; \mathrm{P}<0,0001$; geriye dönük olarak). Maternal serum MDA değerleri açısından ise; $\mathrm{T}$ zamanındaki MDA düzeyi $(6,42 \pm 1,70) \mathrm{T}_{1}(8,43 \pm 2,67)$ ve $\mathrm{T}_{2}(8,80$ $\pm 3.11)$ 'den daha düşük bulunurken $(\mathrm{P}<0,0001$, her ikisi için), $\mathrm{T}_{1}$ ve $\mathrm{T}_{2}$ zamanlarındaki MDA seviyeleri benzerdi $(\mathrm{P}>0,05)$ (Tablo 2). Kord kanı MDA seviyeleri $(9,98 \pm 1,70)$ ise $T_{1}, T_{2}$ ve $\mathrm{T}_{3}$ zamanlarında alınan maternal serum MDA düzeylerinden daha yüksekti $(\mathrm{P}=0,001 ; \mathrm{T}$, için ve $\mathrm{P}<0,0001 ; \mathrm{T}_{1}$ ve $\mathrm{T}_{3}$ için). Spearman korelasyon testi sonucunda, maternal serum MDA ve BDNF seviyeleri arasında negatif korelasyon bulundu ( $\mathrm{r}=-0,374 ; \mathrm{P}<0,0001)$ (Sekil 1). Aynı zamanda kord kanı MDA ve BDNF düzeyleri arasinda da negatif korelasyon izlendi ( $\mathrm{r}=$ $-0,310 ; \mathrm{P}=0,014$ ) (Şekil 2). Maternal ve kord kanı BDNF seviyeleri ile demografik ve klinik özellikleri arasında korelasyon tespit edilmedi.

\section{TARTIŞMA}

Çalışmamızda normal doğum eylemi sırasinda maternal BDNF ve MDA düzeylerindeki değişimler araştırıldı ve maternal BDNF seviyeleri kord kanı BDNF seviyeleri ile karşılaştırıldı. Doğum eyleminin başlangıcında ve doğumun hemen ardından alınan maternal serum BDNF düzeylerinin birbirine benzer olduğu, doğumdan 24 saat sonra ise maternal serum BDNF seviyelerinin yükseldiği bulundu. Ayrıca, maternal serum BDNF düzeyleri her aşamada kord kanı BDNF düzeylerinden yüksekti. Aynı zamanda maternal serum BDNF ile MDA düzeyleri ve kord kanı BDNF ile MDA seviyeleri arasinda negatif korelasyon tespit edildi. Nörotrofinlerin bir üyesi olan BDNF, nöronal fonksiyonların normal olarak sürdürülmesinde önemli role sahiptir (1). BDNF, nöronal ve glial dokuların yanısıra; ımmun hücreler ve vasküler

Tablo 1: Hastaların klinik ve demografik özellikleri.

\begin{tabular}{|l|c|}
\hline Maternal yaş (Y1) & $28,77 \pm 2,96$ \\
\hline Maternal vücud kitle indeksi (kg/m2) & $24,38 \pm 1,32$ \\
\hline Gebelik haftası & $38,79 \pm 0,63$ \\
\hline Parite & $2,64 \pm 0,95$ \\
\hline Yenidoğanın doğum ağırlı̆̆ $(\mathrm{g})$ & $3563,70 \pm 188,64$ \\
\hline Yenidoğanın 1. dakika Apgar skoru & $7,51 \pm 0,53$ \\
\hline Yenidoğanın 5. dakika Apgar skoru & $9,29 \pm 0,49$ \\
\hline Doğum süresi (saat) & $8,00 \pm 0,76$ \\
\hline Yenidoğanın cinsiyeti (erkek/kız) & $32 / 30$ \\
\hline Kord kanı pH değeri & $7,22 \pm 0,01$ \\
\hline
\end{tabular}

Sonuçlar, ortalama \pm standart sapma olarak verildi.

Tablo 2: Maternal serum ile kord kanı örneklerindeki BDNF (pg/ml) ve MDA ( $\mu \mathrm{mol} / \mathrm{ml})$ seviyeleri.

\begin{tabular}{|l|c|c|}
\hline & BDNF & MDA \\
\hline T1 & $956,75 \pm 291,47$ & $8,43 \pm 2,67$ \\
\hline T2 & $985,50 \pm 291,91$ & $8,80 \pm 3,11$ \\
\hline T3 & $3729,92 \pm 621,68^{* *}$ & $6,42 \pm 1,70^{* *}$ \\
\hline Kord kan1 & $834,91 \pm 235,73 \beta$ & $9,98 \pm 1,70^{*}$ \\
\hline
\end{tabular}

Sonuçlar, ortalama \pm standart sapma olarak verildi. T1,2,3: Maternal serum örneklerinin sonuçları; T1: Doğumun latent fazında alınan kan; T2: Göbek kordonu klemplenmeden hemen önce alınan kan; T3: Doğumdan 24 saat sonra alınan kan. $\beta: \mathrm{P}<0,0001$; T3'deki değerler; $\beta: \mathrm{P}=0,002$; T2' deki değerler; $\beta: \mathrm{P}=0,01$, T1'deki değerler ile karşılaştırıld1ğında. *:P<0,0001, T1 ve T3'deki değerler; *:P=0,001, T2'deki değerler ile karşılaştırıldığında. **:P<0,0001, T1 ve T2'deki değerler ile karşılaştırıldığında. 


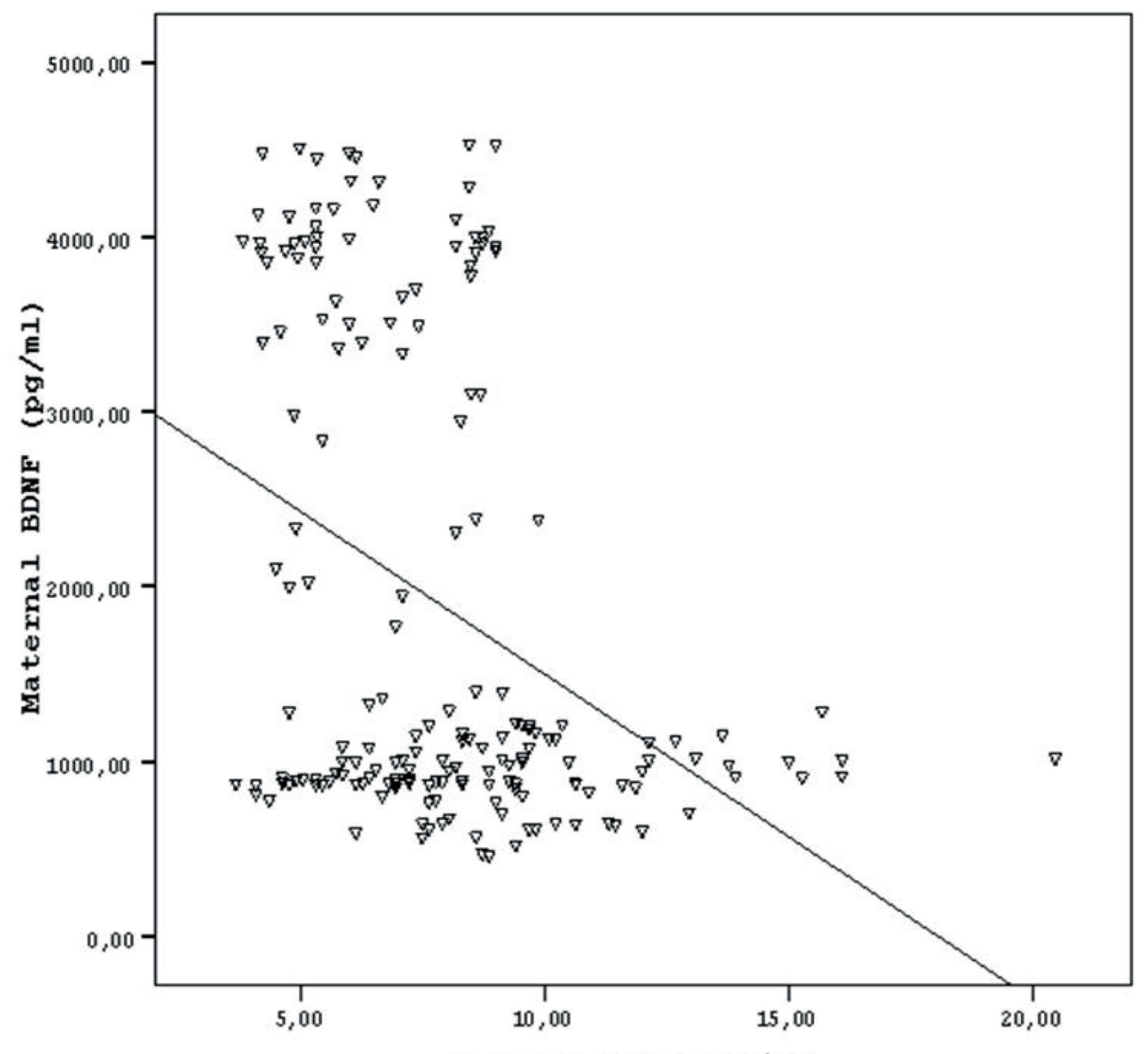

Maternal MDA ( $1 \mathrm{~mol} / \mathrm{ml})$

Şekil 1: Maternal serum MDA ile BDNF seviyeleri arasındaki negatif korelasyon $(r=-0,374 ; \mathrm{P}<0,0001)$.

endotel hücreleri gibi nöronal olmayan dokular tarafindan da sentezlenir (11). BDNF'nin uteroplasental bariyeri geçerek beyin gelişiminde etkili olduğu (12) ve umblikal kord hücrelerinin BDNF salınımında rol aldığı (13) gösterilmiştir. Ayrıca BDNF’nin nöronlarda apoptozisi önlediği ve nörotransmitter salınmında önemli etkileri olduğu rapor edilmiștir $(14,2)$. Hatta Ferrer ve ark. (15) serebral iskemi oluşturulan bir rat modelinde, BDNF uygulanımını takiben kortikal hücre ölümünde azalma olduğunu bildirmişlerdir.

Normal vajinal doğum, uterin kontraksiyonlar, ve tekrarlayan vajinal muayeneler nedeniyle kadınlar için stresli bir durumdur. Doğum sırasında oluşan ağrı, nöroendokrin sistemde stres cevabının oluşmasına neden olur ve hiperventilasyon sonucu oksijen tüketimi artar, kalp atımı hizlanır ve maternal-fetal morbidite ve mortalite riski artar (16). Santral sinir sisteminde strese yol açan travma, hipotansiyon ve se- rebral iskemi gibi durumların BDNF salınımını değiştirdiği rapor edilmiştir (17). Ayrıca kortikal BDNF seviyelerinin dolaşımdaki BDNF seviyeleri ile korele olduğu (4), BDNF sentezi ile sitokin üretimi arasında bağlantı olduğu (18) ve artan oksidatif stresin BDNF salınımın azaltt1ğ1 (19) bilinmektedir. Yapılan çalışmalar gebelerde doğum zamanı yaklaştıkça doğum ağrısı korkusunun ve doğum sirasında yaşanacaklar ile ilgili endişelerin arttığını göstermektedir $(20,21)$. Çalışmamızda, anneden ilk alınan kan numünesi ile doğumun hemen ardından alınan kan örneklerinde benzer MDA ve BDNF seviyeleri tespit edildi. Bunun nedeni anneden alınan ilk kan örneğinin doğumun latent fazının başladığ 1 dönemde alınmış olması olabilir. Çünkü bu dönem, hastanın doğum eyleminin başlaması nedeni ile hastaneye yatırıldı $\breve{g}_{1}$ ve doğum ağrisı korkusunun başladiğı dönemdir. Yani, ilk kan numünesi doğum eylemi henüz başlamadan hastanın kontrol amaçlı hastaneye başvurduğu dönemde alınsaydı sonuçlar farklı 
çıkabilirdi. Nitekim, doğum şeklinin oksidatif stres markırları üzerindeki etkisini araștıran bir çalışmada; gebe kadınlardan ilk kan örnekleri 37-40. gebelik haftaları arasında, henüz doğum eylemi başlamadan alınmıș ve bu kan örneklerindeki oksidatif stres markır seviyelerinin doğumun bitiminde alınan kan örneklerindeki değerlerden düşük olduğu gözlenmiştir (22). Dermitzaki ve ark. (23) ise gerek cerrahi stres gerekse doğum stresinin maternal serum sitokin seviyelerinin değiştirebileceği hipotezini kurmuşlar ve genel anestezi ile bölgesel anestezinin bir oksidatif stres göstergesi olan maternal serum IL-6 seviyeleri üzerine olan etkisini araștırmıșlardır. Elektif sezaryene alınan hastaların seçildiği bu çalışmada, her iki grupta da maternal kan örneklerindeki IL-6 düzeyi için, bebeğin doğumunun hemen ardından alınan kan örneklerindeki seviyeler ile ameliyat öncesi alınan kan örneklerindeki seviyeler arasında fark bulamamışlardır. Bu sonuç çalışmamızdaki sonuçlara benzer niteliktedir.
Çalıșmamızda, doğumdan 24 saat sonraki alınan kan örneklerinde; doğumun latent fazı ve doğumun hemen ardından alınan kan örneklerine göre daha yüksek BDNF ve daha düşük MDA değerleri olduğunu gözlemledik. $\mathrm{Bu}$ sonucu elde etmemizde en önemli etken, bu dönemde annenin rahatlaması, doğum ağrısı korkusunun ve doğum ağrılarının sona ermesi olabilir. Başka bir faktör ise; doğum sonrası annenin emzirmeye başlaması ile artan prolaktin düzeylerinin annedeki stresi azaltıcı ve beyin dokusundan salgılanan BDNF düzeylerinin artırıcı etkisi olabilir. Prolaktin; nörotransmitter ve nöropeptidlerin metabolizmasinı etkileme, bağıșıklık sistemini düzenleme ve stress cevab1 olușturma gibi santral sinir sistemi üzerinde önemli etkilere sahiptir (24). Prolaktin hormonu bu etkilerini reseptörleri aracılığı ile gösterir ve beynin birçok bölgesinde ve en fazla olarak ise koroid pleksusta prolaktin reseptörlerinin yer aldığı rapor edilmiştir (25). Nitekim yapılan çalışmalar, laktasyonun hipokampüsta akut

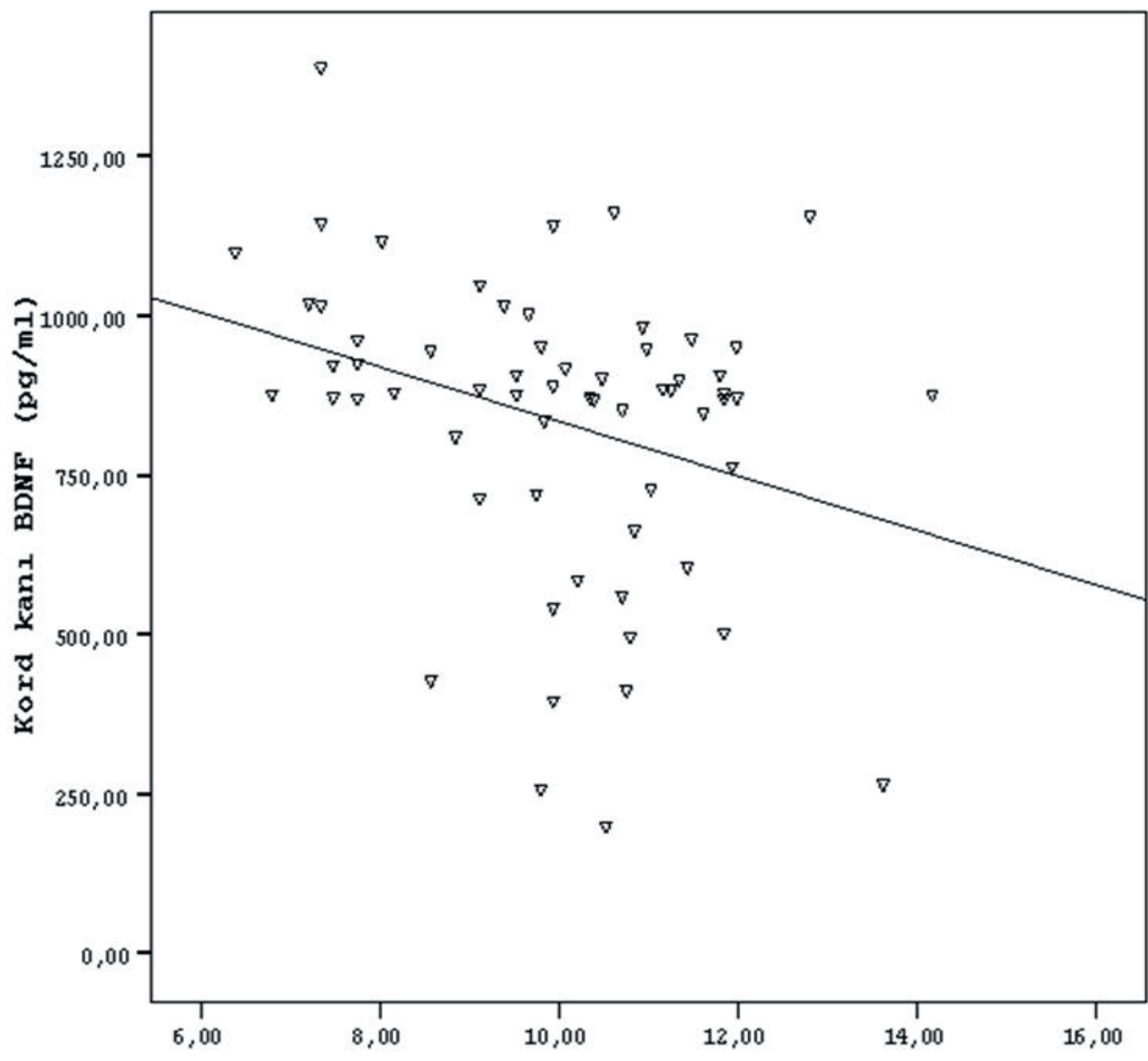

Kord $\mathrm{L}$ anl $\mathrm{MDA}(\mathrm{\mu m} 01 / \mathrm{m} 1)$

Şekil 2: Kord kanı MDA ile BDNF düzeyleri arasındaki negatif korelasyon $(\mathrm{r}=-0,310 ; \mathrm{P}=0,014)$. 
ve kronik hücre hasarını önlediğini ve nöroprotektif etki sağladığını göstermektedir $(26,27)$. BDNF, uteroplasental bariyeri geçerek fetal beyin gelişiminde rol alır (12). Chouthai ve ark. (3) term infantların preterm infantlardan daha yüksek BDNF seviyelerine sahip olduklarını ve gebelik haftasi ile kord kanı BDNF seviyeleri arasında pozitif korelasyon bulunduğunu rapor etmişlerdir. Diğer taraftan, Malamitsi-Puchner ve ark. (28) intrauterin gelişme geriliği (IUGR) olan fetüslerin IUGR olmayan fetüslere benzer düzeyde BDNF seviyelerine sahip olduklarını, ayrıca annelerin yenidoğanlardan daha yüksek BDNF düzeylerine sahip olduğunu bildirmişlerdir. Bizim çalışmamızda da benzer şekilde; doğum eyleminin başlangıcında, doğumun hemen ardından ve doğumdan 24 saat sonra anneden alınan tüm maternal kan örneklerindeki BDNF seviyelerinin kord kanı BDNF seviyelerinden yüksek olduğu gözlendi. Bir lipid peroksidasyon ürürnü olan MDA bir oksidatif stres göstergesidir ve gelișmekte olan fetüsteki artan hücresel aktiviteye bağli olarak gebelikte önemli rol oynar (8). Artan oksidatif stres nörotrofik faktörlerin salınımını azaltabilir (19). Dhobale ve ark. (29) maternal BDNF ile maternal MDA arasında ve kord kanı BDNF ile kord kanı MDA seviyeleri arasında negative korelasyon bulmuşlardır. Çalışmamızda da bu sonuçlara benzer şekilde maternal BDNF ile MDA ve kord kanı BDNF ile MDA seviyeleri arasinda negatif korelasyon bulundu.

Literatür taramamızda spontan vajinal doğum eylemindeki hastalarda maternal BDNF paternindeki değişiklikleri araştıran başka bir çalışmaya rastlamadık. Çalışmamızın kısıtlılı$\breve{g}$, doğumdan 24 saat sonra yenidoğanlardaki BDNF düzeylerinin ölçülmemiş olmasıdır. Ancak, Malamitsi-Puchner ve ark. (28) yenidoğan bebeklerde doğumun hemen ardından, doğumdan 24 saat sonra ve 4 gün sonra alınan alınan serum örneklerindeki BDNF seviyelerinin benzer olduğunu rapor etmişlerdir. Çalışmamıza dahil edilen denek sayısina belirli bir zaman diliminde kliniğimize başvuran hastalar değerlendirilerek ulaşılmıştır. Ổncesinde güç analizinin olmaması çalışmamızın diğer kısıtlılığıdır. Sonuç olarak, çalışmamızda spontan vajinal doğum eylemindeki kadınlarda; doğumun latent fazında ve doğum eyleminin bitiminin hemen ardından alınan maternal serum örneklerinde benzer BDNF seviyeleri gözlendi. Ancak doğumdan 24 saat sonra alınan maternal serum örneklerindeki BDNF seviyelerinin bu değerlerden daha yüksek olduğu bulundu. Aynı zamanda kord kanı BDNF seviyelerinin maternal BDNF seviyelerinden her aşamada daha düşük olduğu izlendi. Ayrıca maternal serum BDNF ile MDA seviyeleri arasında ve kord kanı BDNF ile MDA seviyeleri arasında negatif korelasyon bulundu. Bu sonuçlar spontan vajinal doğum yapan kadınlarda maternal BDNF salınımında değişiklikler olduğunu göstermektedir. $\mathrm{Bu}$ değişiklikler, doğum eylemi sırasında artan maternal oksidatif stres ile ilişkilidir. Sonuçlarımızın desteklenmesi için daha çok sayıda hasta içeren ve epidural anestezi gibi ağrısız doğum yöntemlerinin kullanıldığı ikinci bir grup ile karşılaştırma yapılan daha geniş kapsamlı araştırmalar gerekmektedir.

\section{KAYNAKLAR}

1. Huang EJ, Reichardt LF. Neurotrophins: roles in neuronal development and function. Annu Rev Neurosci 2001;24:677-736

2. Chao MV, Rajagopal R, Lee FS. Neurotrophin signalling in health and disease. Clin Sci (Lond) 2006; 110(2):167-173.

3. Chouthai NS, Sampers J, Desai N, Smith GM. Changes in neurotrophin levels in umbilical cord blood from infants with different gestational ages and clinical conditions. Pediatr Res 2003;53(6):965-969.

4. Karege F, Schwald M, Cisse M. Postnatal developmental profile of brain derived neurotrophic factor in rat brain and platelets. Neurosci Lett 2002;328(3):261-264.

5. Kenna HA, Reynolds-May M, Stepanenko A, Ketter TA, Hallmayer J, Rasgon NL. Blood levels of brain derived neurotrophic factor in women with bipolar disorder and healthy control women. J Affect Disord 2014;156:214-218.

6. O'Keefe LM, Doran SJ, Mwilambwe-Tshilobo L, Conti LH, Venna VR, McCullough LD. Social isolation after stroke leads to depressive-like behavior and decreased BDNF levels in mice. Behav Brain Res 2014;260:162-170.

7. Koo JW, Park CH, Choi SH, Kim NJ, Kim HS, Choe JC, Suh YH. The postnatal environment can counteract prenatal effects on cognitive ability, cell proliferation, and synaptic protein expression. FASEB J 2003; 17(11):1556-1558.

8. Girotti AW. Lipid hydroperoxide generation, turnover, and effector action in biological systems. $J$ Lipid Res 1998;39(8):1529-1542.

9. Stanzani L, Zoia C, Sala G, Appollonio I, Frattola L, De Simoni MG, Ferrarese C. Nerve growth factor and transforming growth factor-beta serum levels in acute stroke patients. Possible involvement of neurotrophins in cerebrovascular disease. $\mathrm{Ce}$ rebrovasc Dis 2001;12(3):240-244.

10. Ohkawa H, Ohishi N, Yagi K. Assay for lipid peroxides in animal tissues by thiobarbituric acid reaction. Anal Biochem 1979;95(2):351-358. 
11. Nakahashi T, Fujimura H, Altar CA, Li J, Kambayashi J, Tandon NN, Sun B. Vascular endothelial cells synthesize and secrete brain-derived neurotrophic factor. FEBS Lett 2000;470(2):113-117.

12. Kodomari I, Wada E, Nakamura S, Wada K. Maternal supply of BDNF to mouse fetal brain through the placenta. Neurochem Int 2009;54(2):95-98.

13. Fan CG, Zhang QJ, Tang FW, Han ZB, Wang GS, Han ZC. Human umbilical cord blood cells express neurotrophic factors. Neurosci Lett 2005;380(3):322-325.

14. Miller FD, Kaplan DR. Neurotrophin signalling pathways regulating neuronal apoptosis. Cell Mol Life Sci 2001;58(8):1045-1053.

15. Ferrer I, Krupinski J, Goutan E, Marti E, Ambrosio $S$, Arenas E. Brain-derived neurotrophic factor reduces cortical cell death by ischemia after middle cerebral artery occlusion in the rat. Acta Neuropathol 2001;101(3):229-238.

16. Brownridge P. The nature and consequences of childbirth pain. Eur J Obstet Gynecol Reprod Biol 1995;59:9-15.

17. Hicks RR, Martin VB, Zhang L, Seroogy KB. Mild experimental brain injury differentially alters the expression of neurotrophin and neurotrophin receptor $m R N A s$ in the hippocampus. Exp Neurol 1999; 160(2):469-478.

18. Marshall JS, Gomi K, Blennerhassett MG, Bienenstock $J$. Nerve growth factor modifies the expression of inflammatory cytokines by mast cells via a prostanoid-dependent mechanism. J Immunol 1999;162(7):4271-4276.

19. Kapczinski F, Frey BN, Andreazza AC, Kauer-Sant'Anna M, Cunha AB, Post RM. Increased oxidative stress as a mechanism for decreased BDNF levels in acute manic episodes. Rev Bras Psiquiatr 2008;30(3):243-245.

20. Rouhe H, Salmela-Aro K, Halmesmäki E, Saisto T. Fear of childbirth according to parity, gestational age, and obstetric history. BJOG2009;116(1):67-73
21. Alipour Z, Lamyian M, Hajizadeh E, Vafaei MA. The association between antenatal anxiety and fear of childbirth in nulliparous women: a prospective study. Iran J Nurs Midwifery Res 2011;16(2):16973.

22. Vakilian K, Ranjbar A, Zarganjfard A, Mortazavi $M$, Vosough-Ghanbari S, Mashaiee S, Abdollahi $M$. On the relation of oxidative stress in delivery mode in pregnant women; a toxicological concern. Toxicol Mech Methods 2009;19(2):94-99.

23. Dermitzaki E, Staikou C, Petropoulos G, Rizos $D$, Siafaka I, Fassoulaki A. A randomized study of maternal serum cytokine levels following cesarean section under general or neuraxial anesthesia. Int $J$ Obstet Anesth 2009;18(1):33-37.

24. Ben-Jonathan N, LaPensee CR, LaPensee EW: What can we learn from rodents about prolactin in humans? Endocr Rev 2008;29 (1): 1-41.

25. Tabata H, Kobayashi M, Ikeda JH, Nakao N, Saito TR, Tanaka M: Characterization of multiple first exons in murine prolactin receptor gene and the effect of prolactin on their expression in the choroid plexus. J Mol Endocrinol 2012;48 (2), 169-176.

26. Morales T. Recent findings on neuroprotection Trats. J Neuroendocrinol 2011;23(11):994-1001.

27. Donner N, Bredewold R, Maloumby R, Neumann ID. Chronic intracerebral prolactin attenuates neuronal stress circuitries in virgin rats. Eur $J$ Neurosci 2007;25(6):1804-1814.

28. Malamitsi-Puchner A, Economou E, Rigopoulou $O$, Boutsikou T. Perinatal changes of brain-derived neurotrophic factor in pre- and fullterm neonates. Early Hum Dev 2004;76(1):17-22.

29. Dhobale $M$, Mehendale $S$, Pisal H, Nimbargi $V$, Joshi S. Reduced maternal and cord nerve growth factor levels in preterm deliveries. Int J Dev Neurosci 2012;30(2):99-103. 